\title{
RECOLONIZATION OF SUBSTRATES BURNED IN THE 1988 Yellowstone PARK Fires by CRYPTOGaMs (LiCHENS, MosSES, FungI)
}

\section{SHARON EVERSMAN $\downarrow$ DEPARTMENT OF ECOLOGY MONTANA STATE UNIVERSITY $\uparrow$ BOZEMAN}

\begin{abstract}
$\downarrow \quad$ INTRODUCTION
The fires of 1988 in Yellowstone National Park burned 1.1 million acres (1719.4 square miles) within the park boundaries, about $44.5 \%$ of the park. Six per cent of the area burned was meadowgrassland and $94 \%$ was forests. Most of the forested areas that burned were dominated by lodgepole pine (Pinus contorta Dougl. ex Loud), with smaller tracts of Douglas fir (Pseudotsuga menziesii (Mirbel) Franco)), Engelmann spruce (Picea engelmannii Parry) and whitebark pine (Pinus albicaulis Engelm.). The burns were mosaic in nature, leaving different sizes of areas severely burned, moderately burned and unburned, and adjacent patches of mostly ground fires, mostly canopy fires, both ground and canopy fires or unburned stands (Rothermel et al, 1994).
\end{abstract}

Many park projects have documented recovery of vascular plants, especially lodgepole pine and the understory perennials (Anderson \& Romme, 1991; Baskin, 1999; Foster, et al, 1999; Reed, et al, 1999; Tomback, et al, 2001; Turner et al, 1994, 1997). The conclusions were that lodgepole pine has regenerated itself, as expected, from seed sources in adjacent unburned patches. Herbaceous and shrubby understory regeneration has depended primarily on the plants that were present at the study sites before the fires, with regrowth from surviving underground parts as well as from nearby seed sources. This study investigates the initial return of non-vascular vegetation, lichens and mosses, all of which were presumably destroyed when their substrates were burned. None of the other Yellowstone studies included cryptogam observations.

Studies concentrating on recolonizing cryptogamic crusts, including mosses, algae and lichens, on dryland soil after fires, have occurred in Utah (Johansen, et al, 1984) and Australia (Eldridge \& Bradstock, 1994). Algae tended to return before lichens and mosses, especially during wet years, and after five years the lichens and mosses were recovering but not yet to pre-burn cover. Researchers have found that, on limestone, two lichen species colonized after four years. Thomas, et al (1994) found that Ceratodon purpureus appeared to be insensitive to $\mathrm{pH}$ differences of burned peat surfaces and readily colonized ashed surfaces within one year after fire; Polytrichum piliferum was dominant after three years.

Recent studies of recolonization by lichens and mosses on soil in burned northern coniferous forest have been more long-term and documented the increase in cryptogam cover as time since fire increases. In a spruce-lichen woodland in eastern Canada, crustose lichens and Cladonia species dominated 4-30 years after fire, with Cladina dominating after 40 years (Treter 1995). It was found that species of Polytrichum and Cladonia, with some Peltigera species and Stereocaulon alpinum, to be the primary colonizers $0-50$ years after fire in a lodgepole pine forest in British Columbia. Cladina species were the major cryptogamic ground cover 
after 50-100 years. Brulisauer, et al (1996) documented the importance of Polytrichum species and Pohlia nutans $0-50$ years post-fire, with Cladina, Peltigera and Pleurozium schreberi increasing in ground cover after 50 years. Stability in bryophyte communities was reached within 100 years, but organizational changes among lichens, shrubs, forbs and grasses were still occurring after 100 years (Brulisauer, et al., 1996).

Studies focusing on wood and bark recolonization after fire, have documented colonization of burned Quercus ilex stumps by Cladonia spp., Agonimia allobata and Macentina dictyospora within 11 years after fire. It has been shown that following the initial recolonization of burned Quercus hypoleucoides in southern Arizona, trees with rough-textured bark close to healthy lichens were recolonized first by Flavopunctelia praesignis and Punctelia hypoleucites.

The objective of this study was to document the initial return of lichens and mosses in 2001, 13 years (growing seasons) after the 1988 fires were extinguished. We examined burned wood substrates, soil and rock. In addition to identifying the recolonizing species, thallus sizes of lichens were measured to provide insight into recolonization and growth rates. Eversman et al (2002) identified 369 lichen species from Yellowstone Park, and related distributions of species to vegetation types. We identified 256 species in Engelmann spruce stands, 206 in Douglas fir, 133 in lodgepole pine/whitebark pine and 152 in lodgepole pine stands. Since so many more lichen species had been found in the moister forest types, we hypothesized that there would be significant differences in the recolonization patterns among the forests - that more species and larger thalli would be found in the burned, recovering Engelmann spruce and Douglas fir stands than in lodgepole pine and whitebark pine stands. A complete moss inventory of the park has not been completed; the Yellowstone National Park Herbarium has 120 species in 57 genera. The working hypothesis was also that there would be more and different moss species in the moister burned sites.

\section{METHODS AND LOCATIONS}

Five burned meadow sites and 27 sites in burned forest stands were selected: eleven in lodgepole pine, five in whitebark pine, six in Douglas fir and five in Engelmann spruce forests. Elevation of meadow sites were 2090-2165 m. Engelmann spruce sites varied from 2152-2383 m; Douglas fir, 1940-
$2202 \mathrm{~m}$; whitebark pine $2527-2637 \mathrm{~m}$, and lodgepole pine sites from 2033-2364m. Most of the sites were on hillsides with various exposures; three lodgepole pine sites were on level ground. Since most of the forests burned were lodgepole pine, those sites were easily found; burned stands from the other three forest type were more difficult to locate. Positive identification of type of burn site was made by identifying adjacent tree types, incompletely burned trees and type of tree reproducing. Each site was about $0.25-5.0$ hectare in size. A loop was walked through the site, recording lichen and moss species on ten completely blackened logs lying horizontally (downed logs) and standing burned stumps or snags, when present, and on soil. A snag is most of a burned, standing tree approximately its original height and a stump is standing remains short enough to be able for us to easily observe its topmost parts (i.e., about $1.5 \mathrm{~m}$ or less). Samples of all species were taken for voucher specimens, and for laboratory identification when field identification was uncertain. We measured the sizes of lichen thalli or colonies of Cladonia on burned wood substrates and patches of moss and lichen on soil that had without doubt been burned. Original plans were to sample rocks also, but it was not always obvious if we were looking at rocks that had been completely burned, so that part of the study was minimized.

\section{$\downarrow \quad$ RESULTS AND DISCUSSION}

\section{General Patterns}

As expected, the percentage of recolonized burned wood substrates was highest in Engelmann spruce sites (81.6\%) and Douglas fir sites (80.5\%), and lower in the lodgepole pine $(66.1 \%)$ and whitebark pine stands (62.6\%) (Table 1). Engelmann spruce and Douglas fir sites were usually in mosaic burns, with unburned trees and associated unburned soil and rock, within five to $50 \mathrm{~m}$ of sampled logs and snags. Whitebark pine sites were usually farther, as much as $1 \mathrm{~km}$, from unburned trees. Lodgepole pine sites varied from being adjacent to unburned trees to $1.5 \mathrm{~km}$ from unburned trees. Logs and stumps/snags that were not bare had lichens only, mosses only, or both as recolonizers. Small polypore fungi and tiny ascomycetes (C. Cripps, pers. comm.) were frequently on the burned wood, and occasional oyster mushrooms (Pleurotus sp.) were also seen. Decorticated logs lying horizontally, and not apparently burned, were very common in the lodgepole pine sites; they had no moss or lichen growth on them at all, just occasional small ascomycetes. No lichen or moss growth was observed on any of the conifers that have regrown 
since 1989; most of them were lodgepole pine, with Engelmann spruce, Douglas fir and subalpine fir in moister sites, and none more than about $5 \mathrm{~m}$ tall. A few whitebark pines were regenerating the burned whitebark pine areas, but most of the young pines in those sites also were lodgepole pine.

\begin{tabular}{|c|c|c|c|c|}
\hline \multicolumn{5}{|c|}{$\begin{array}{l}\text { Table 1. Percentages of pre burned wood and burned wood substrates with recolonizing lichens, mosses, } \\
\text { and fungi. The first number of each pair in each column is the number of sites in each forest type in which } \\
\text { the species or bare logs occurred. The second number is the percentage of burned wood surfaces on which } \\
\text { each species occurred. Forest types are listed in approximate order from most moist to driest. }\end{array}$} \\
\hline Forest type & \begin{tabular}{|l|} 
Engelmann \\
\end{tabular} & Douglas & Whitebark & Lodgepole \\
\hline & Spruce & Fir & Pine & Pine \\
\hline Number of sites & 5 & 6 & 5 & 11 \\
\hline Number of burned wood substrates & 74 & 97 & 53 & 167 \\
\hline \multicolumn{5}{|l|}{ (total of all sites) } \\
\hline & & & & \\
\hline Bare logs, stumps, snags & $4 / 18.4$ & $6 / 19.5$ & $5 / 37.4$ & $10 / 33.9$ \\
\hline Recolonized logs, stumps, snags & $5 / 81.6$ & $5 / 81.6$ & $6 / 80.5$ & $5 / 62.6$ \\
\hline Moses & $5 / 64.0$ & $5 / 41.8$ & $5 / 41.6$ & $9 / 38.9$ \\
\hline \multicolumn{5}{|l|}{ Ceratodon purpureus, } \\
\hline \multicolumn{5}{|l|}{ Bryum caespiticium } \\
\hline Lichens (total) & $5 / 64.8$ & $6 / 62.2$ & $5 / 56.6$ & $11 / 44.3$ \\
\hline Bryoria fuscescens & 212.7 & $2 / 4.1$ & - & $5 / 5.4$ \\
\hline Candelariella aurella & - & $1 / 2.1$ & - & - \\
\hline Cladonia squamules & $5 / 43.2$ & $4 / 11.3$ & $4 / 20.8$ & $8 / 16.2$ \\
\hline Cladonia fimbriata & $4 / 24.3$ & $4 / 6.2$ & - & $4 / 4.8$ \\
\hline Cladonia coniocraea & $2 / 4.1$ & $1 / 1.0$ & - & $21 \quad 1.8$ \\
\hline Lepraria cacumimum & & & 213.8 & \\
\hline Letharia vulpina & 216.8 & $4 / 13.4$ & - & $4 / 2.4$ \\
\hline Melanelia exasperatula & $1 / 1.4$ & $4 / 11.3$ & $1 / 1.9$ & $4 / 3.6$ \\
\hline Parmelia sulcata & $1 / 1.4$ & $1 / 1.0$ & - & 210.6 \\
\hline Parmeliopsis ambigua & $1 / 2.7$ & $4 / 6.2$ & $1 / 1.9$ & 210.6 \\
\hline Peltigera rufescens & & & & \\
\hline Phuscia adscendens & $\frac{1 / 1.4}{-}$ & $\frac{2 / 3.1}{3 / 4.1}$ & $\frac{-}{-}$ & - \\
\hline Physcia dubia, dimidiata & $2 / 2.7$ & $6 / 5.2$ & $5 / 17.0$ & 113.0 \\
\hline Usnea substerilis & $4 / 9.5$ & $6 / 23.7$ & - & $8 / 12.6$ \\
\hline Xanthoparmelia sp. & - & $1 / 1.0$ & - & - \\
\hline Xanthoria fulva & $2 / 2.7$ & $6 / 32.0$ & $1 / 1.9$ & $3 / 4.8$ \\
\hline Soredia (white, yellow) & $3 / 4.1$ & $3 / 3.1$ & $1 / 1.9$ & $5 / 6.6$ \\
\hline
\end{tabular}

Mosses: Burned Wood

Moss recolonization was significantly greater $(\mathrm{P}<.05$, Student's t-tests $)$ in the Engelmann spruce sites $(64.0 \%)$ than in the lodgepole pine, whitebark pine and Douglas fir sites (38.9 - 41.8\%) (Table 1). Of 27 forest stands, Ceratodon purpureus and Bryum caespiticium were on burned wood in 24 sites. If cover had been recorded, the percentage for moss cover would have been much greater than lichen cover. The general pattern for moss growth was for Ceratodon and B. caespiticium to apparently start growing on the soil directly under the logs, and expand continuously upwards onto the logs, particularly in cracks in the wood and on the uphill or more shaded side of the logs. On most logs with mosses, the moss growth was a thin green film in cracks with small gametophytes and no sporophytes, giving a green shimmery appearance to the blackened logs. On the bases of snags and stumps, again, moss growth was continuous with the same species growing on the adjacent soil.

In moister sites, including stands in Engelmann spruce Douglas fir and lodgepole pine, mosses other than $C$. purpureus and B. caespiticium on burned wood were Aulacomnium palustre, Brachythecium rutabulum, Brachythecium sp., Bryum capillare, Dicranum sp. Drepanocladus uncinatus (=Sanionia uncinata), Leptobryum pyriforme, Plagiothecium denticulatum, Pohlia nutans, and Rhytidiopsis robusta. They tended to be on shaded logs or the bases of burned stumps and snags, growing up onto the wood from the soil, and most of them did not have sporophytes. Specimens of all the moss recolonizers, except $R$. robusta, were already part of the collection in the Yellowstone National Park Herbarium (J. Whipple, Pers. Comm.).

\section{Mosses: Soil}

The major moss species on burned soil were Bryum spp., especially B. caespiticium, Ceratodon purpureus, Polytrichum juniperinum and $P$. piliferum. Tortula ruralis was in drier lodgepole pine and meadow sites. Ceratodon and B. caespiticium were in all 27 sites, either on logs or on soil, or both. The Polytrichum species were in 11 sites, evenly distributed among forest types, and their mats reached maximum diameters of $50-60 \mathrm{~cm}$. Polytrichum seemed to never grow from soil upwards onto wood substrates. Marchantia polymorpha was in two of the wettest spruce sites. Funaria hygrometrica, a usual fire species, was not seen; it may have been present immediately after the fires and replaced by Ceratodon and Bryum. Pohlia nutans, a common colonizer in other burn studies (Brulisauer, et al, 1996), likewise was not found in this study.

\section{Mosses: Rocks}

Most rhyolite and granitic outcrops and boulders had no moss growth at all directly on the rock, but there was usually Ceratodon around the bases. The mosses in cracks in the rock, again usually growing up from the soil, were Ceratodon purpureus and Bryum caespiticium.

\section{Lichens: Burned Wood}

Lichen recolonization on all burned wood substrates was highest in spruce sites (64.8\%), and lowest in the lodgepole pine sites (44.3\%) (Table 1); a greater difference was expected. The largest number of species (15 plus soredia) was in Douglas fir types. There are probably two explanations for this observation. Two large leaning Douglas fir trees that had been burned but still retained some charred bark contributed to the unusually high presence of Melanelia exasperatula, Parmeliopsis ambigua, Physcia adscendens, Letharia vulpina, Usnea 
substerilis and Xanthoria fulva. It could be that, even though the bark was completely blackened, rhizines were not destroyed and regrowth occurred from those protected parts. In addition, three Douglas fir sites were immediately adjacent to unburned stands of Douglas fir, and propagules from the unburned sites could have easily reached those logs examined.

Sterile Cladonia squamules, C. fimbriata and $C$. coniocraea accounted for the greatest amount of recolonization on burned wood (Table 1). Their usual location was in shaded horizontal cracks toward the bottoms of logs lying on the ground. Logs that were propped up from the ground by other logs or stumps, and the sides of standing snags and stumps, had the least amount of recolonization by either lichens or moss. The most favorable place for the lichens on stumps was in concave depressions at the tops, which perhaps accumulated more moisture and apparently provided rough surfaces, on which Xanthoria fulva and the fruticose species (Bryoria fuscescens, Letharia vulpina, Usnea substerilis) readily attached. Many small individual threads of the fruticose species frequently gave a hairy appearance to the blackened wood.

Lichens were recolonizing burned wood in all forest types, but only five lichens were in all forest types: Cladonia squamules, Melanelia exasperatula, Parmeliopsis ambigua, Physcia spp. and Xanthoria fulva, plus yellow and white soredia. Bryoria fuscescens, Cladonia fimbriata, C. coniocraea, Letharia vulpina, and Usnea substerilis were in all forest types except whitebark pine.

The sources of propagules for the mosses and lichens are presumed to be nearby unburned trees. The distance from the burn sites to unburned sites ranged from a few meters (adjacent unburned trees or across a road or creek) to over $1 \mathrm{~km}$ from unburned lodgepole pine. Spruce and Douglas fir sites were in mosaic burns, with unburned trees a generally few meters from the burned logs and snags. Proximity to propagule sources and hillsides less exposed to drying winds probably help account for more recolonization. Whitebark pine sites were on tops of ridges and mountains, most exposed and usually not close to unburned trees. Lodgepole pine sites were variable, with a range of distances between burned trees and unburned trees - from sites more than $1 \mathrm{~km}$ from unburned lodgepole pine to mosaic sites.

\section{Lichens: Soil}

Peltigera rufescens, and occasional $P$. didactyla, were on burned soil in ten of the 27 sites; they were in four Douglas fir sites and two of each of the other forest types. The largest thallus diameters were $30 \mathrm{~cm}$ in an Engelmann spruce site, $19 \mathrm{~cm}$ in a Douglas fir site, $10 \mathrm{~cm}$ in whitebark pine and $6 \mathrm{~cm}$ in a lodgepole pine site. The size differences probably reflect the differences in moisture. Patches of Cladonia squamules not associated with downed logs were seen in only five lodgepole and whitebark pine sites. No other lichen species were observed on soil. Early soil colonizers in other studies have included many more Cladonia species than observed here, as well as Cladina and Stereocaulon species and Trapeliopsis granulosa (Brulisauer et al, 1996).

Where grasses had regenerated well, there were no mosses or lichens on soil. In drier sagebrush-grassland, cyanobacteria (Nostoc), Cladonia chlorophaea, Peltigera rufescens, Tortula ruralis, Bryum caespiticium, and Ceratodon purpureus were on soil. Woody plant debris, usually the remains of Artemisia tridentata, was covered with Rinodina turfacea, Buellia papillata, Caloplaca cerina and Xanthoria fulva.

\section{Lichen: Rock}

Most of the burned rhyolite observed in lodgepole pine stands had little or no returning lichen or moss growth. When they were being recolonized, however, the returning species of lichens were scattered areoles and occasional apothecia of Candelariella aurella, Lecanora novomexicana, Lecanora polytropa and Lecidea atrobrunnea. Aspicilia spp. and Rhizocarpon geographicum, in patches of about $1 \mathrm{~cm}$ in diameter, may also have been on burned rock.

Granite boulders were somewhat richer in recolonizing species. In addition to the six lichen species mentioned above, Physcia dubia, Umbilicaria hyperborea and Xanthoria elegans, all with thalli of about $1 \mathrm{~cm}$ in size, were on granite in meadow sites.

\section{Lichen Colonization and Growth}

Twelve of the lichens recolonizing burned wood are sorediate, and Melanelia exasperatula is isidiate, apparently indicating the dispersal efficiency of soredia and isidia. The non-sorediate lichen species, Candelariella aurella, Lepraria cacuminum and Peltigera rufescens, are abundant throughout the park. All of the species identified from the burned substrates were among the most common and widespread lichen species in forests in Yellowstone National Park (Eversman et al., 2002), providing 
propagules for burned sites.

Table 2 gives the largest thalli recorded for 15 lichen species in each forest type; where the two largest thalli were the same size, only one number was given. The size was divided by 13 (13 years since 1989) for an estimated growth rate. The rate includes establishment time which is not exactly known, but assumed to be 1989 for the largest thalli.

\begin{tabular}{|c|c|c|c|c|}
\hline Lichen & $\begin{array}{l}\text { Engelmann } \\
\text { Spruce }\end{array}$ & $\begin{array}{l}\text { Douglas } \\
\text { Fir }\end{array}$ & \begin{tabular}{|l|}
$\begin{array}{l}\text { Whitebark } \\
\text { Pine }\end{array}$ \\
\end{tabular} & $\begin{array}{l}\text { Whitebark } \\
\text { Pine }\end{array}$ \\
\hline Bryoria fuscescens & $\begin{array}{r}18,32 \\
1.4,2.5 \\
\end{array}$ & $\begin{array}{l}20,44 \\
1.5,3.4 \\
\end{array}$ & $\begin{array}{l}0 \\
0 \\
\end{array}$ & $\begin{array}{c}32,40 \mathrm{~mm} \\
2.5,3.1 \mathrm{~mm} / \text { year }\end{array}$ \\
\hline Cladonia squamules & $\begin{array}{r}50,180 \\
3.8,13.8 \\
\end{array}$ & $\begin{array}{r}25,30 \\
1.9,2.3 \\
\end{array}$ & $\begin{array}{r}19,35 \\
1.5,2.7 \\
\end{array}$ & $\begin{array}{r}55,60 \\
4.2,4.6 \\
\end{array}$ \\
\hline Cladonia coniocraea & $\begin{array}{c}24,70 \\
1.8,5.4 \\
\end{array}$ & $\begin{array}{l}20 \\
1.5 \\
\end{array}$ & $\begin{array}{l}0 \\
0 \\
\end{array}$ & $\begin{array}{c}3.5,5 \\
0.4,2.7\end{array}$ \\
\hline Cladonia fimbriata & $\begin{array}{r}60,77 \\
4.6,5.9 \\
\end{array}$ & $\begin{array}{l}15 \\
1.2 \\
\end{array}$ & $\begin{array}{l}0 \\
0 \\
\end{array}$ & $\begin{array}{r}70,75 \\
5.4,5.8 \\
\end{array}$ \\
\hline Letharia vulpina & $\begin{array}{c}5,6 \\
0.4,0.5 \\
\end{array}$ & $\begin{array}{c}8,9 \\
0.6,0.7 \\
\end{array}$ & $\begin{array}{l}0 \\
0\end{array}$ & $\begin{array}{r}20,30 \\
1.5,2.3 \\
\end{array}$ \\
\hline Melanelia exasperatula & $\begin{array}{r}4,6 \\
0.3,0.5 \\
\end{array}$ & $\begin{array}{c}24,32 \\
1.8,2.5 \\
\end{array}$ & $\begin{array}{c}5 \\
0.4 \\
\end{array}$ & $\begin{array}{r}30,32 \\
2.3,2.5\end{array}$ \\
\hline Parmeliopsis anbigua & $\begin{array}{r}12,13.5 \\
0.9,1.08 \\
\end{array}$ & $\begin{array}{r}15,20 \\
1.2,1.5 \\
\end{array}$ & $\begin{array}{l}0 \\
0\end{array}$ & $\begin{array}{c}4 \\
0.3\end{array}$ \\
\hline Parmelia sulcata & $\begin{array}{c}8 \\
0.6\end{array}$ & $\begin{array}{c}6.5,8 \\
0.5,0.6 \\
\end{array}$ & $\begin{array}{l}0 \\
0\end{array}$ & $\begin{array}{r}16,25 \\
1.2,1.9 \\
\end{array}$ \\
\hline Physcia dubia, dimidiata & $\begin{array}{r}2,3 \\
0.2,0.2 \\
\end{array}$ & $\begin{array}{r}11,12 \\
0.8,0.9 \\
\end{array}$ & $\begin{array}{r}35 \\
2.7 \\
\end{array}$ & $\begin{array}{c}5,7 \\
0.4,0.5\end{array}$ \\
\hline Plyscia adscendens & $\begin{array}{l}0 \\
0\end{array}$ & $\begin{array}{c}7 \\
0.5\end{array}$ & $\begin{array}{l}0 \\
0\end{array}$ & $\begin{array}{l}0 \\
0\end{array}$ \\
\hline Usnea substerilis & $\begin{array}{c}6,7 \\
0.5,0.5 \\
\end{array}$ & $\begin{array}{r}12,16 \\
0.9,1.2 \\
\end{array}$ & $\begin{array}{l}0 \\
0 \\
\end{array}$ & $\begin{array}{r}12,14 \\
0.9,1.1 \\
\end{array}$ \\
\hline Xanthoparmelia sp. & $\begin{array}{l}0 \\
0\end{array}$ & $\begin{array}{c}8 \\
0.6\end{array}$ & $\begin{array}{l}0 \\
0 \\
\end{array}$ & $\begin{array}{l}0 \\
0\end{array}$ \\
\hline Xanthoria fulva & $\begin{array}{c}3,4 \\
0.2,0.3\end{array}$ & $\begin{array}{c}7,20 \\
0.5,1.5\end{array}$ & $\begin{array}{c}2 \\
0.2\end{array}$ & $\begin{array}{c}3,4 \\
0.2,0.3\end{array}$ \\
\hline
\end{tabular}

On burned wood, continuous Cladonia squamules can establish in cracks of logs quite efficiently in favorable areas, e.g., about $14 \mathrm{~mm}$ per year in a spruce site. Among the fruticose species, Bryoria fuscescens appeared to have the fastest growth rate (3.1 to $3.4 \mathrm{~mm}$ per year) in Douglas fir and lodgepole pine sites, respectively. The rate appeared faster than those of Letharia vulpina (maximum of $2.3 \mathrm{~mm} / \mathrm{year}$ ) and Usnea substerilis $(1.2 \mathrm{~mm} /$ year). Among foliose species, a particularly robust specimen of Physcia dubia reached a size of $35 \mathrm{~mm}(2.7 \mathrm{~mm} /$ year$)$, followed by Melanelia exasperatula, with growth rates of about 2.5 $\mathrm{mm} /$ year. White and yellowish soredia were present at many sites, indicating the presence of propagules that had not yet developed into identifiable species.

On soil, the most common species was Peltigera rufescens. The largest thallus of this species was in a Douglas fir site, with a size of $115 \mathrm{x}$
$150 \mathrm{~mm}$, for a growth rate of about 8.8 to $11.5 \mathrm{~mm}$ per year. Peltigera rufescens was in all forest types, with maximum thallus diameters of 68 to $100 \mathrm{~mm}$; it was more common in Douglas fir and spruce sites. A common genus on soils, Cladonia, was only in lodgepole pine sites, with a maximum colony diameter of $100 \mathrm{~mm}$ (7.7 mm/year growth rate). Ground cover by tall graminoids and forbs inhibited growth of moss and lichen cover in most Douglas fir and spruce sites.

The working hypothesis - more lichen species and larger thalli in Engelmann spruce and Douglas fir sites - was partially supported by data collected during 2001. The largest number of lichen species colonizing burned substrates was in Douglas fir sites, with 15 identifiable species present (Table 1). Twelve species were in Engelmann spruce and lodgepole pine sites, and six were in the relatively barren, highest-elevation whitebark pine sites. Moss growth was significantly greater in the more shaded Engelmann spruce sites. Growth rates of Cladonia spp., Parmeliopsis ambigua and Parmelia sulcata were slightly faster in Engelmann spruce and Douglas fir sites, but that was not necessarily true for Xanthoria fulva and Bryoria fuscescens, Letharia vulpina and Usnea substerilis.

Apparently the most common and abundant species of lichens establish themselves early in postfire succession and remain indefinitely since all of the colonizing species are also present in old forests. Greater diversity occurs with time, but also is apparently related to favorable habitats, the Douglas fir and Engelmann spruce forests (Eversman et al. 2002).

\section{REFERENCES CITED}

Anderson, J. E. \& W. H. Romme. 1991. Initial floristics in lodgepole pine (Pinus contorta) forests following the 1988 Yellowstone fires. International Journal of Wildland Fire 1: $119-124$

Baskin, Y. 1999. Yellowstone fires: a decade later: ecological lessons learned in the wake of the conflagration. Bioscience 49: 93-97.

Brulisauer, A. R., G. E. Bradfield \& J. Maze. 1996. Quantifying organizational change after fire in lodgepole pine forest understorey. 1996. Canadian Journal of Botany 74: 1773-1782. 
Eldridge, D. J. \& R. A. Bradstock. 1994. The effect of time since fire on the cover and composition of cryptogamic soil crusts on a eucalypt-shrubland soil. Cunninghamia 3: 521-527.

Eversman, S., C. M. Wetmore, K. Glew \& J. P. Bennett. 2002. Patterns of lichen diversity in Yellowstone National Park. The Bryologist 105: 27-42.

Foster, D. R., D. H. Knight \& J. F. Franklin. 1998. Landscape patterns and legacies resulting from large, infrequent forest disturbances. Ecosystems 1: 497-510.

Johansen, J. R., L. L. St. Clair, B. L. Webb \& G. T. Nebeker. 1984. Recovery patterns of cryptogamic soil crusts in desert rangelands following fire disturbance. The Bryologist 87: 238-243.

Reed, R. A., M. E. Finley, W. H. Romme \& M. Turner. 1999. Aboveground net primary production and leaf-area index in early postfire vegetation in Yellowstone National Park. Ecosystems 2: 88-94.
Rothermel, R. C., R. A. Hartford \& C. H. Chase. 1994. Fire growth maps for the 1988 Greater Yellowstone Area fires. U. S. D. A. Forest Service, Intermountain Research Station, General Technical Report INT-304. $64 \mathrm{pp}$.

Tomback, D. F., A. J. Anderies, K. S. Carsey, M. L. Powell, S. Mellman-Brown. 2001. Delayed seed germination and regeneration patterns following the Yellowstone fires. Ecology: 2587-2600.

Treter, U. 1995. Fire-induced succession of lichenspruce woodland in Central LabradorUngava, Canada. Phytocoenologia 25: 161183.

Turner, M., W. H. Romme \& R. H. Gardner. 1994. Landscape disturbance models and the longterm dynamics of natural areas. Natural Areas Journal 14: 3-11.

Turner, M., W.H. Romme, R.H. Gardner \& W. W. Hargrove. 1997. Effects of fire size and pattern on early succession in Yellowstone National Park. Ecological Monographs 67: 411-433. 